\title{
KOMUNIKASI ANTAR BUDAYA DALAM PERSPEKTIF ANTROPOLOGI
}

Oleh:

\section{Khoiruddin Muchtar, Iwan Koswara, Agus Setiaman}

\author{
khoiruddin@uinsgd.ac.id
}

\section{Pendahuluan}

Aplikasi perspektif antropologi dalam komunikasi antar budaya adalah melihat komunikasi antar budaya dari sudut pandang antropologi, karena di dalam komunikasi tersebut sudah terkandung nilai-nilai budaya. Komunikasi antar budaya adalah bagian perkawinan antara disiplin antropologi dan komunikasi yang kemudian menjadi disiplin tersendiri baik dalam ilmu komunikasi maupun dalam antropologi.

Antropologi merupakan salah satu bidang ilmu yang menjadi akar atau landasan lahirnya ilmu komunikasi. Pada perkembangan selanjutnya para ahli budaya menyadari akan pentingnya komunikasi dalam bidang budaya.

Definisi yang pertama dikemukakan didalam buku "Intercultural Communication: A Reader" dimana dinyatakan bahwa komunikasi antar budaya (intercultural communication) terjadi apabila sebuah pesan (message) yang harus dimengerti dihasilkan oleh anggota dari budaya tertentu untuk konsumsi anggota dari budaya yang lain (Samovar \& Porter, 1994, p. 19).

Alo Liliweri (2003, p. 13) mendefinisikan proses komunikasi antar budaya sebagai interaksi antarpribadi dan komunikasi antarpribadi yang dilakukan oleh beberapa orang yang memiliki latar belakang kebudayaan yang berbeda. Apapun definisi yang ada mengenai komunikasi antar budaya (intercultural communication) menyatakan bahwa komunikasi antar budaya terjadi apabila terdapat 2 (dua) budaya yang berbeda dan kedua budaya tersebut sedang melaksanakan proses komunikasi.

Secara spesifik menurut Linton (1945: 32), budaya merupakan konfigurasi prilaku manusia dari elemen-elemen yang ditransformasikan oleh anggota masyarakat. Secara umum budaya telah dianggap sebagai milik manusia dan digunakan sebagai alat komunikasi sosial yang didalamnya terdapat proses imitasi (peniruan).

Antropologi dikatakan sebagai salah satu akar atau landasan lahirnya ilmu komunikasi. Seiring dengan perkembangan antropolgi tersebutlah akhirnya para ahli budaya melihat jika dalam budaya juga sangat tergantung pada komunikasi. Hal inilah yang kemudian dikaji mengenai proses dari komunikasi tersebut sehingga lahirlah ilmu 
komunikasi dari antroplogi. Namun untuk lebih jelasnya mengenai keterkaitan tersebut sebaiknya kita terlebih dahulu melihat menganai antopologi dan komunikasi itu sendiri.

Kebudayaan adalah komunikasi simbolis, simbolisme itu adalah keterampilan kelompok, pengetahuan, sikap, nilai, dan motif. Makna dari simbol-simbol itu dipelajari dan disebarluaskan dalam masyarakat melalui institusi. Menurut Levo-Henriksson (1994), kebudayaan itu meliputi semua aspek kehidupan kita setiap hari, terutama pandangan hidup - apapun bentuknya - baik itu mitos maupun sistem nilai dalam masyarakat. Ross (1986,hlm 155) melihat kebudayaan sebagai sistem gaya hidup dan ia merupakan faktor utama (common domitor) bagi pembentukan gaya hidup (Alo Liliweri, 2003,8-9.

\section{Antropologi Sosial Budaya}

Adalah Kuntjaraningrat dalam bukunya "Pengantar Antropologi1"(1996) menjelaskan bahwa secara akademis, antropologi adalah sebuah ilmu tentang manusia pada umumnya dengan titik fokus kajian pada bentuk fisik, masyarakat dan kebudayaan manusia. Sedangkan secara praktis, antropologi merupakan sebuah ilmu yang mempelajari manusia dalam beragam masyarakat suku bangsa, guna membangun masyarakat suku bangsa tersebut (Agusyanto dkk, 2007: 1.4)

Dalam antropologi sosial budaya, manusia merupakan komponen penting bagi dirinya dan bagi alam lingkungannya. Ada hubungan yang saling berkaitan dan saling mempengaruhi antara manusia dan alam lingkungannya.

Manusia sebagai makhluk sosial harus selalu hidup bersama. Manusia selalu hidup bersama secara kolektif dalam kesatuan-kesatuan sosial yang besar maupun kecil. Dalam kesatuan sosial inilah manusia hidup saling berinteraksi, bekerja sama, dan bertukar pengetahuan untuk dapat mencapai tujuan hidupnya.

Alam semesta ini akan selalu berputar sesuai dengan hukum alam (sunatullah), maka tidak akan ada satu makhlukpun yang bisa terhindar dari hukum alam, termasuk manusia juga akan terkena hukum alam. Manusia adalah makhluk pilihan karena mempunyai kelebihan akal. Maka dalam perjalanan hidupnya manusia akan selalu belajar untuk mendapatkan hasil kreasi cipta, karsa, dan rasa yang kemudian disebut dengan budaya. Budaya adalah hasil rekayasa manusia sebagai upaya untuk memperbaiki dan meningkatkan taraf hidupnya.

Hasil kreasi budaya manusia menjadi landasan norma dan nilai untuk mengatur dan menata kehidupan manusia dlam upaya mencapai perkembangan hidup yang beradab. Klukhohn (1953) merumuskan 7 unsur kebudayaan yaitu: (1) Sistem teknologi, yaitu peralatan dan perlengkapan hidup menusia (pakaian, perumahan, alat-alat rumah tangga, senjata, alat-alat produksi transport dan sebagainya. (2) Sistem mata pencaharian 
hidup dan sistem-sistem ekomoni (pertanian, peternakan, sistem produksi, sistem distribusi dan lainnya). (3) Sistem kemasyarakatan (sistem kekerabatan, organisasi politik, sistem hokum dan sistem perkawinan). (4) Bahasa (lisan dan tulisan). (5) Kesenian (seni rupa, seni suara, seni gerak dan sebagainya). (6) Sistem pengetahuan dan (7) sistem kepercayaan. (Burhan Bungin, 2006: 53).

Nilai budaya dan struktur sosial merupakan substansi dari aspek sosial manusia. Manusia hidup di alam semesta ini mengikuti alur perkembangan sosial beserta gejalagejalanya. Dalam kehidupan manusia diantarkan oleh suatu sistem sosial yang terdiri dari struktur-struktur sosial. Dalam struktur sosial tersebut terjalin hubungan anatar individuindividu dan kelompok-kelompok. Disitu ada dua hubungan diadik, yaitu hubungan individu atau kelompok kesatu dengan pihak kedua, akan tetapi berbeda antara satu pihak dengan pihak yang lain. Bentuk dan struktur sosial biasanya tetap, terkadang juga berubah, akan tetapi perubahan itu berjalan lamban, sedangkan individu dan kelompok yang ada dalam struktur sosial selalu berubah (Koentjaraningrat, 1987: 180)

Di dalam kelompok-kelompok sosial ada beberapa nilai dan norma yang disepakati bersama, gunanya adalah untuk mengatur status dan peranan manusia dalam struktur sosial. Nilai merupakan sebuah kepercayaan yang didasarkan pada kode etik yang berlaku dalam masyarakat. Nilai dan norma memberikan arahan kepada manusia mengenai apa yang benar dan salah, baik dan buruk, memberikan pedoman hidup untuk masa sekarang dan akan datang. Dimensi dari nilai adalah satuan interelasi dari beberapa nilai yang ada dalam sebuah kelompok kepentingan.

Hubungan manusia dalam kehidupan sosial budayanya dijelaskan dalam sistem relasional. Nilai merupakan sebuah unsur penting dalam kebudayaan, karena menentukan tentang sesuatu itu boleh atau tidak boleh dilakukan.

\section{Memahami Komunikasi dan Budaya}

Komunikasi lintas budaya terjadi bila pengirim pesan adalah anggota dari suatu budaya dan penerima pesannya adalah anggota dari suatu budaya yang lain. Oleh karena itu, sebelum membicarakan Komunikasi Lintas Budaya lebih lanjut kita akan membahas konsep komunikasi dan budaya dan hubungan diantara keduanya terlebih dahulu.

Pembicaraan tentang komunikasi akan diawali dengan asumsi bahwa komunikasi berhubungan dengan kebutuhan manusia dan terpenuhinya kebutuhan berinteraksi dengan manusia-manusia lainnya. Kebutuhan berhubungan sosial ini terpenuhi melalui 
pertukaran pesan yang berfungsi sebagai jembatan untuk mempersatukan manusiamanusia yang tanpa berkomunikasi akan terisolasi.

Dari uraian di atas dapat disimpulkan bahwa komunikasi merupakan proses penyampaian pesan dari seorang komunikator kepada komunikan. Dan proses berkomunikasi itu merupakan sesuatu yang tidak mungkin tidak dilakukan oleh seseorang karena setiap perilaku seseorang memiliki potensi komunikasi.

Proses komunikasi melibatkan unsur-unsur sumber (komunikator), Pesan, media, penerima dan efek. Disamping itu proses komunikasi juga merupakan sebuah proses yang sifatnya dinamik, terus berlangsung dan selalu berubah, dan interaktif, yaitu terjadi antara sumber dan penerima.Proses komunikasi juga terjadi dalam konteks fisik dan konteks sosial, karena komunikasi bersifat interaktif sehingga tidak mungkin proses komunikasi terjadi dalam kondisi terisolasi. Konteks fisik dan konteks sosial inilah yang kemudian merefleksikan bagaimana seseorang hidup dan berinteraksi dengan orang lainnya sehingga terciptalah pola-pola interaksi dalam masyarakat yang kemudian berkembang menjadi suatu budaya.

Adapun budaya itu sendiri berkenaan dengan cara hidup manusia. Bahasa, persahabatan, kebiasaan makan, praktek komunikasi, tindakan-tindakan sosial, kegiatankegiatan ekonomi dan politik dan teknologi semuanya didasarkan pada pola-pola budaya yang ada di masyarakat.

Budaya adalah suatu konsep yang membangkitkan minat. Secara formal budaya didefinisikan sebagai tatanan pengetahuan, pengalaman, kepercayaan, nilai, sikap, makna, hirarki, agama, waktu, peranan, hubungan ruang, konsep alam semesta, objek-objek materi dan milik yang diperoleh sekelompok besar orang dari generasi ke generasi melalui usaha individu dan kelompok.(Mulyana, 1996:18)

Budaya dan komunikasi tak dapat dipisahkan satu sama lain, karena budaya tidak hanya menentukan siapa bicara dengan siap, tentang apa dan bagaimana orang menyandi pesan, makna yang ia miliki untuk pesan, dan kondisi-kondisinya untuk mengirim, memperhatikan dan menafsirkan pesan. Budaya merupakan landasan komunikasi sehingga bila budaya beraneka ragam maka beraneka ragam pula praktekpraktek komunikasi yang berkembang. 


\section{Perbedaan-Perbedaan Budaya}

Budaya adalah gaya hidup unik suatu kelompok manusia tertentu. Budaya bukanlah sesuatu yang dimiliki oleh sebagian orang dan tidak dimiliki oleh sebagian orang yang lainnya - budaya dimiliki oleh seluruh manusia dan dengan demikian seharusnya budaya menjadi salah satu faktor pemersatu.

Pada dasarnya manusia-manusia menciptakan budaya atau lingkungan sosial mereka sebagai suatu adaptasi terhadap lingkungan fisik dan biologis mereka. Individuindividu sangat cenderung menerima dan mempercayai apa yang dikatakan budaya mereka. Mereka dipengaruhi oleh adat dan pengetahuan masyarakat dimana mereka tinggal dan dibesarkan, terlepas dari bagaimana validitas objektif masukan dan penanaman budaya ini pada dirinya. Individu-individu itu cenderung mengabaikan atau menolak apa yang bertentangan dengan "kebenaran" kultural atau bertentangan dengan kepercayaan-kepercayaannya. Inilah yang seringkali merupakan landasan bagi prasangka yang tumbuh diantara anggota-anggota kelompok lain, bagi penolakan untuk berubah ketika gagasan-gagasan yang sudah mapan menghadapi tantangan.

Setiap budaya memberi identitas kepada sekolompok orang tertentu sehingga jika kita ingin lebih mudah memahami perbedaan-perbedaan yang terdapat dalam msaing-masing budaya tersebut paling tidak kita harus mampu untuk mengidentifikasi identitas dari masing-masing budaya tersebut yang antara lain terlihat pada aspek komunikasi dan budaya, sistem komunikasi, verbal maupun nonverbal, membedakan suatu kelompok dari kelompok lainnya. Terdapat banyak sekali bahasa verbal diseluruh dunia ini demikian pula bahasa nonverbal, meskipun bahasa tubuh (nonverbal) sering dianggap bersifat universal namun perwujudannya sering berbeda secara lokal.

Pakaian dan penampilan ini meliputi pakaian dan dandanan luar juga dekorasi tubuh yang cenderung berbeda secara kultural, begitu juga cara memilih, menyiapkan, menyajikan dan memakan makanan sering berbeda antara budaya yang satu dengan budaya yang lainnya. Subkultur-subkultur juga dapat dianalisis dari perspektif ini, seperti ruang makan eksekutif, asrama tentara, ruang minum teh wanita, dan restoran vegetarian.

Kesadaran akan waktu berbeda antara budaya yang satu dengan budaya lainnya. Sebagian orang tepat waktu dan sebagian lainnya merelatifkan waktu. Suatu cara untuk mengamati suatu budaya adalah dengan memperhatikan cara dan metode memberikan pujian bagi perbuatan-perbuatan baik dan berani, lama pengabdian atau bentuk-bentuk 
lain penyelesaian tugas. Budaya juga mengatur hubungan-hubungan manusia dan hubungan-hubungan organisasi berdasarkan usia, jenis kelamin, status, kekeluargaan, kekayaan, kekuasaan, dan kebijaksanaan.

Berdasarkan sistem nilai yang dianutnya, suatu budaya menentukan normanorma perilaku bagi masyarakat yang bersangkutan. Aturan ini bisa berkenaan dengan berbagai hal, mulai dari etika kerja atau kesenangan hingga kepatuhan mutlak atau kebolehan bagi anak-anak; dari penyerahan istri secara kaku kepada suaminya hingga kebebasan wanita secara total.

Kenyamanan yang dimiliki seseorang atas dirinya bisa diekspresikan secara berbeda oleh masing-masing budaya. Beberapa budaya sangat terstruktur dan formal, sementara budaya linnya lebih lentur dan informal. Beberapa budaya sangat tertutup dan menentukan tempat seseorang secara persis, sementara budaya-budaya lain lebih terbuka dan berubah.

Beberapa budaya menekankan aspek perkembangan otak ketimbang aspek lainnya sehingga orang dapat mengamati perbedaan-perbedaan yang mencolok dalam cara orang-orang berpikir dan belajar. Semua budaya tampaknya mempunyai perhatian terhadap hal-hal supernatural yang jelas dalam agama-agama dan praktek keagamaan atau kepercayaan mereka.

\section{Hubungan Komunikasi dan Budaya}

Penelitian membuktikan bahwa tidak akan ada dua masyarakat yang sama persis di dunia ini. Lingkungan fisik ataupun psikis akan membantu manusia dalam menyesuaikan diri, sekaligus membuatnya berbeda antara satu dengan yang lainnya. Hal ini berimplikasi juga pada sistem komunikasi yang hidup dalam masyarakat tersebut.

Setiap masyarakat akan mempuntai sistem komunikasi sendiri-sendiri, maka dengan sendirinya demi kelangsungan hidupnya,setiap masyarakat dapat membentuk kebudayaannya (Depdikbud, 1995:21). Bahasa menjadi inti dari komunikasi sekaligus sebagai pembuka realitas bagi manusia. Kemudian dengan komunikasi, manusia membentuk masyarakat dan kebudayaannya. Sehingga bahasa secara tidak langsung turut membentuk kebudayaan pada manusia.

Kebudayaan mencakup semua hal yang dimiliki bersama oleh suatu masyarakat. Suatu kebudayaan mengandung semua pola kebiasaan-kebiasaan suatu masyarakat, seperti dalam bidang ekonomi, religi, hukum, kesenian, sistem ekonomi, pengetahuan, 
kepercayaan dan sebagainya. Kebudayaan sangat berarti banyak bagi masyarakat dan individu-individu di dalamnya, karena kebudayaan mengajarkan manusia untuk selalu hidup selaras dengan alam, sekaligus memberikan tuntunan untuk berinteraksi dengan sesamanya. Kebudayaan dan religi merupakan dua hal yang tidak bisa dipisahkan begitu saja, terkadang kebudayaan merefleksikan cara beribadah dalam kepercayaan yang dianut oleh manusia.

Dari sekian banyak kegunaan budaya, para pakar antropologi percaya bahwa bahasalah yang memegang peranan utama dalam perkembangan budaya manusia, karena bahasa merupakan wahana utama untuk meneruskan adat istiadat dari generasi satu ke generasi lainnya. Kemampuan manusia dalam membangun tradisi budaya, menciptakan pemahaman tentang realita yang diungkapkan secara simbolik, dan mewariskan kepada generasi penerusnya, sangat tergantung pada bahasa.

Melalui urian tersebut terlihat bagaimana kaitan antara bahasa, budaya, dan komunikasi, dalam kehidupan sosial budaya. Bahasa hidup dalam komunikasi untuk menciptakan budaya, kemudian budaya itu sendiri yang pada akhirnya akan menentukan sistem komunikasi dan bentuk bahasa seperti apa yang pantas untuknya (Kuswarno, 2008: 11)

Setelah para ahli menelaah hubungan antara bahasa dan komunikasi, atau antara bahasa dan kebudayaan, mulailah dipikirkan pendekatan yang melibatkan bahasa,komunikasi, dan kebudayaan secara bersamaan, mengingat ketiganya sangat erat. Kemudian laihirlah apa yang disebut dengan etnografi komunikasi. Inilah yang menjadi dasar rujukan komunikasi antar budaya.

Hubungan antara komunikasi dan kebudayaan secara konseptual terkonsentarasi pada hubungan perlintasan komunikasi verbal dan non verbal antar kelompok sosial dalam masyarakat. Maka komunikasi antar budaya umumnya mempelajari beberapa hal diantaranya adalah: pertama, kode dan saluran meliputi cara berbicara, teori dan penelitian verbal, teknik komunikasi internasional, bahasa dan politik, kebudayaan visual, dan analisis diskursus komunikasi serta kebudayaan, kedua, praktek kebudayaan, contoh retorika dan masyarakat, politik budaya, media dan kebijakan dalam negeri,komunikasi antar pribadi, aplikasi kritik teori dalam media massa, media gender dan ras, ketiga, metode penelitian meliputi metode penelitian kualitatif dan kuantitatif, penelitian lapangan dalam komnukasi, analisis isi, kritik retorika, dan peneliitan filsafat.

Komunikasi antar budaya merupakan komunikasi antara orang-orang yang berbeda kebudayaannya, misalnya antara suku bangsa, etnik dan ras atau kelas sosial, samovar dan porter juga mengatakan bahwa komunikasi antar budaya terjadi diantara produsen 
pesan dan penerima pesan dengan latar kebudayaan yang berbeda (Samovar dkk, 1976: 4)

Komunikasi antar budaya meliputi komunikasi yang melibatkan peserta yang mewakili pribadi, antar pribadi, kelompok dengan tekanan perbedaan latar belakang kebudayaan yang mempengaruhi perilaku komunikasi para peserta.

Komunikasi antar budaya adalah proses komunikasi simbolik, interpretatif, transaksional, kontektual yang dilakukan oleh sejumlah orang. Karena memberikan derajat kepentingan, mereka memberikan interpretasi dan harapan secara berbeda terhadap apa yang disampaikan dalam bentuk prilaku tertentu sebagai makna yang dipertukarkan (Lusting dan Koester, 1993)

Komunikasi antar budaya adalah proses negosiasi atau pertukaran sistem simbolik yang membimbing perilaku manusia dan membatasi mereka dalam menjalankan fungsinya sebagai kelompok. Identitas dan perbedaan profesi yang terjadi membentuk satu kelompok dan mengidentifikasinya dengan cara yang beragam (Liliweri, 2005 :368)

Manusia dalam konteks komunikasi antar budaya yaitu selalu berkomunikasi dengan dengan sesamanya melintasi ruang dan waktu. Semua kontek tersebut sering kali ada dalam benak manusia, namun perlu difahami bahwa konteks itu merupakan kombinasi yang melibatkan para peserta komunikasi yang mengisi ruang dan waktu komunikasi.

Untuk menentukan salah satu kunci efektif komunikasi antar budaya adalah pengakuan faktor-faktor pembeda yang mempengaruhi peserta komunikasi, apa itu etnik, rasa atau kelompok kategori, yang memiliki kebudayaan tersendiri. Perbedaanperbedaan itu meliputi nilai, norma, kepercayaan, bahas, sikap dan persepsi, semuanya sangat menentukan pola-pola komunikasi antar budaya. Kalau perbedaan itu tidak kita sadari maka akan mengakibatkan kesalah fahaman, prasangka, stereotif dan sikap diskriminatif.

Komunikasi secara fenomenologis tidak tidak bisa berdiri sendiri, komunikasi memerlukan disiplin ilmu lain, karena fenomena sosial bukanlah realitas yang berdiri sendiri, fenomena yang tampak merupakan objek yang penuh dengan makna transendental.

Bila dilihat dari keseluruhan gambar maka akan ada hubungan fungsional antara antropologi dengan komunikasi antar budaya. Kerangka konsep yang bisa dibangun dari gambar ini adalah proses interaksi simbolik dalam etnografi komunikasi antar budaya, karena menjelaskan seluruh aspek sosial budaya manusia dan pola hubungan antar manusia dengan masing-masing kelompoknya. Akan tetapi pada gambar ini dapat menjelaskan keberlangsungan proses komunikasi antar budaya. Gambar ini belum bisa 
menjelaskan tentang peristiwa komunikasi antar manusia yang berlatar belakang agama, pengalmaan dan kebudayaan.

\section{Hambatan Komunikasi Antar Budaya}

Hambatan komunikasi atau yang juga dikenal sebagai communication barrier adalah segala sesuatu yang menjadi penghalang untuk terjadinya komunikasi yang efektif (Chaney \& Martin, 2004, p. 11). Contoh dari hambatan komunikasi antabudaya adalah kasus anggukan kepala, dimana di Amerika Serikat anggukan kepala mempunyai arti bahwa orang tersebut mengerti sedangkan di Jepang anggukan kepala tidak berarti seseorang setuju melainkan hanya berarti bahwa orang tersebut mendengarkan. Dengan memahami mengenai komunikasi antar budaya maka hambatan komunikasi (communication barrier) semacam ini dapat kita lalui.

Hambatan dalam komunikasi antar budaya mempunyai bentuk seperti sebuah gunung es yang terbenam di dalam air. Dimana hambatan komunikasi yang ada terbagi dua menjadi yang diatas air (above waterline) dan dibawah air (below waterline). Faktorfaktor hambatan komunikasi antar budaya yang berada dibawah air (below waterline) adalah faktor-faktor yang membentuk perilaku atau sikap seseorang, hambatan semacam ini cukup sulit untuk dilihat atau diperhatikan. Jenis-jenis hambatan semacam ini adalah persepsi (perceptions), norma (norms), stereotip (stereotypes), filosofi bisnis (business philosophy), aturan (rules),jaringan (networks), nilai (values), dan grup cabang (subcultures group).

Merujuk kepada Chaney \& Martin, (2004: p. 11 - 12) terdapat sembilan jenis hambatan komunikasi antar budaya yang berada diatas air (above waterline). Hambatanhambatan tersebut adalah, Pertama, Fisik, berasal dari hambatan waktu, lingkungan, kebutuhan diri, dan juga media fisik. Kedua, budaya, hambatan ini berasal dari etnik yang berbeda, agama, dan juga perbedaan sosial yang ada antara budaya yang satu dengan yang lainnya. Ketiga, Persepsi, Jenis hambatan ini muncul dikarenakan setiap orang memiliki persepsi yang berbeda-beda mengenai suatu hal. Sehingga untuk mengartikan sesuatu setiap budaya akan mempunyai pemikiran yang berbeda-beda.

Keempat Motivasi, hambatan ini berkaitan dengan tingkat motivasi dari pendengar, maksudnya adalah apakah pendengar yang menerima pesan ingin menerima pesan tersebut atau apakah pendengar tersebut sedang malas dan tidak punya motivasi sehingga dapat menjadi hambatan komunikasi. Kelima pengalaman, jenis hambatan yang terjadi karena setiap individu tidak memiliki pengalaman hidup yang sama sehingga setiap individu mempunyai persepsi dan juga konsep yang berbeda-beda dalam melihat sesuatu. Keenam Emosi, hambatan ini berkaitan dengan emosi atau perasaan pribadi 
dari pendengar. Apabila emosi pendengar sedang buruk maka hambatan komunikasi yang terjadi akan semakin besar dan sulit untuk dilalui.

Ketujuh Bahasa, Hambatan komunikasi ini terjadi apabila pengirim pesan dan penerima pesan menggunakan bahasa yang berbeda atau penggunaan kata-kata yang tidak dimengerti oleh penerima pesan. Kedelapan Nonverbal, yaitu hambatan komunikasi yang tidak berbentuk kata-kata tetapi dapat menjadi hambatan komunikasi. Contohnya adalah wajah marah yang dibuat oleh penerima pesan (receiver) ketika pengirim pesan (sender) melakukan komunikasi. Wajah marah yang dibuat tersebut dapat menjadi penghambat komunikasi karena mungkin saja pengirim pesan akan merasa tidak maksimal atau takut untuk mengirimkan pesan kepada penerima pesan.

Kesembilan Kompetisi, Hambatan ini muncul apabila penerima pesan sedang melakukan kegiatan lain sambil mendengarkan. Contohnya adalah menerima telepon selular sambil menyetir, karena melakukan 2 (dua) kegiatan sekaligus maka penerima pesan tidak akan mendengarkan pesan yang disampaikan melalui telepon selularnya secara maksimal.

\section{Komunikasi Efektif Antar Budaya}

Kunci komunikasi yang efektif antar budaya adalah pengetahuan. Hal utama yaitu penting bahwa orang-orang memahami permasalahan yang potensial dari komunikasi antar budaya, dan membuat suatu usaha yang sungguh-sungguh untuk mengatasi permasalahan ini. Dan yang kedua adalah penting untuk berasumsi bahwa sebuah usaha tidak akan selalu sukses, dan melakukan penyesuaian terhadap usaha tersebut dengan perilaku yang sewajarnya.

Sebagai contoh, seseorang perlu selalu berasumsi bahwa ada kemungkinan penting mengenai perbedaan budaya akan menyebabkan permasalahan komunikasi, akan wajar dan layak dimaklumi, dan bukannya menjadi agresif dan bermusuhan, jika permasalahan berkembang. Sering kesalahan menafsir adalah sumber masalah. Maka dalam mengatasi konflik yang sedang memanas adalah untuk berhenti, mendengarkan, dan berpikir. Ini juga membantu dalam komunikasi lintas budaya.

Mendengarkan secara aktif kadang dapat digunakan untuk memeriksa out-by berulang yang didengar, seseorang dapat mengkonfirmasikan bahwa seseorang memahami komunikasi tersebut dengan teliti. Jika kata-kata digunakan berbeda antar bahasa atau kelompok budaya mendengarkan aktif dapat mengabaikan kesalahpahaman Para perantara yang terbiasa dengan kultur keduanya dapat menolong situasi komunikasi 
antar budaya. Mereka dapat menterjemahkan kedua unsur dan cara dari apa yang dikatakan.

Sebagai contoh, mereka dapat berbicara lebih pelan pada statemen kuat yang akan dipertimbangkan sesuai kultur yang satu tetapi tidak pada kultur yang lain, sebelum mereka diberikan kepada orang-orang dari kultur yang tidak berbicara bersama-sama dalam suatu cara yang kuat. Mereka dapat juga melakukan penyesuaian pemilihan waktu mengenai apa yang dikatakan dan yang dilaksanakan.

Namun kadang-kadang para perantara dapat membuat komunikasi menjadi lebih sulit lagi. Jika perantara memiliki kultur atau kebangsaan yang sama dengan salah satu dari pembantah, tetapi yang lain tidak, ini akan memberikan penampilan yang menyimpang, bahkan ketika tidak ada yang ada. Bahkan ketika penyimpangan tidak diharapkan, adalah umum bagi perantara untuk lebih yang mendukung atau lebih memahamkan orang yang dari kulturnya, karena dia memahami orang tersebut dengan lebih baik. Namun ketika penengah dari sepertiga kelompok budaya, potensi untuk kesalah pahaman antar budaya meningkat lebih lanjut. Dalam hal ini sangat sesuai jika mulai bekerja ekstra tentang proses dan cara menyelesaikan diskusi, seperti waktu ekstra untuk menetapkan dan mengkonfirmasi ulang pemahaman pada tiap-tiap langkah dalam dialog atau proses negosiasi.

\section{DAFTAR PUSTAKA}

Agusyanto, Rudi dkk, 2007, Pengantar Antropologi, Jakarta, Universitas Terbuka. Bungin, Burhan, 2007, Sosiologi Komunikasi, Jakarta, Fajar Interpratama Grafika.

Kuswarno, Engkus, 2008, Etnografi Komunikasi: suatu Pengantar dan Contoh Penelitiannya, Bandung, Widya Padjadjaran.

Koentjaraningrat, 1987, Sejarah Teori Antropologi, UI Press.

Liliweri, Alo, 2005, Prasangka dan Konflik, Komunikasi Lintas Budaya Masyarakat Multikultur, Yogyakarta LKiS.

Liliweri, Alo. Gatra-Gatra Komunikasi Antar Budaya. Yogyakarta: Pustaka Pelajar, 2001 2003, Makna Budaya dalam Komunikasi Antarbudaya, Yogyakarta: LKIS. 2004, Dasar-dasar Komunikasi Antarbudaya, Yogyakarta: Pustaka Pelajar. 


\section{JURNAL MANAJEMEN KOMUNIKASI}

Leach, Edmund.1976. Culture and Communication, The Logic by which symbols are connected. Cambridge: University Press.

Mulyana, Deddy, dan Jalaluddin Rakhmat. 1996. (Editor) Komunikasi antar Budaya.

Panduan berkomunikasi dengan orang-orang berbeda budaya. Bandung: Remaja Rosda Karya. 2004, Komunikasi Efektif, Suatu Pendekatan Lintasbudaya, Bandung: Remaja Rosda Karya

Nur Syam, 2007, Madzhab-Madzhab Antropologi, Yogyakarta, LKiS.

Samovar, Larry A dan Richard E.Porter,1976, Intercultural Communication : A Reader, California, Wadswoth Publishing Company. 